University for Business and Technology in Kosovo

UBT Knowledge Center

UBT International Conference

2014 UBT International Conference

Nov 8th, 10:15 AM - 10:30 AM

\title{
Concrete of our Millennium - Eco Friendly Concrete
}

\author{
Mevlan Qafleshi \\ Polytechnic University of Tirana \\ Driton R. Kryeziu \\ Polytechnic University of Tirana \\ Lulëzim Bytyçi \\ Polytechnic University of Tirana \\ Fisnik Kadiu \\ Polytechnic University of Tirana
}

Follow this and additional works at: https://knowledgecenter.ubt-uni.net/conference

Part of the Architecture Commons

\section{Recommended Citation \\ Qafleshi, Mevlan; Kryeziu, Driton R.; Bytyçi, Lulëzim; and Kadiu, Fisnik, "Concrete of our Millennium - Eco Friendly Concrete" (2014). UBT International Conference. 13. \\ https://knowledgecenter.ubt-uni.net/conference/2014/all-events/13}

This Event is brought to you for free and open access by the Publication and Journals at UBT Knowledge Center. It has been accepted for inclusion in UBT International Conference by an authorized administrator of UBT Knowledge Center. For more information, please contact knowledge.center@ubt-uni.net. 


\title{
Concrete of our Millennium - Eco Friendly Concrete
}

\author{
Mevlan Qafleshi ${ }^{1}$, Driton R. Kryeziu ${ }^{2}$, Lulëzim Bytyçi ${ }^{3}$, Fisnik Kadiu ${ }^{4}$ \\ ${ }^{1}$ Polytechnic University of Tirana, Faculty of ME\&PhE, Tirana, Albania, \\ ${ }^{234}$ Polytechnic University of Tirana, Faculty of CE, Tirana, Albania,
}

\begin{abstract}
Scientifically there are no more doubts about the impact of humans on global warming. The raise of earth temperature causes environmentally related problems. Evidences show the most influencing GHG is $\mathrm{CO}_{2}$. Many human activities release this GHG as a byproduct. Generally, the two industries contributing to this are the energy production and construction. The GWhrs of Kosovo energy, (in 2013, $5864 \mathrm{GWh}$ ) emit kilotons of $\mathrm{CO}_{2}$. The emission of $\mathrm{CO}_{2}$ in 2013 was $7896.0 \mathrm{kton}$, i.e. $1.3 \mathrm{t} / \mathrm{MWh}$. On the other side, the concrete industry, the second most used material, which uses cement contributes with other tons of GHG, almost each ton of cement contributes with one tone of $\mathrm{CO} 2$ emission. The other negative impact of energy sector is production of combustion byproducts. The interest of this study is the residue in the form of ash- Fly ash, which in terms of production is around $1 \mathrm{Mt}$ annually. In 2013 Fly ash generation was $1.5 \mathrm{Mt}$. This is the physical threat to environment. The aim of this study is the mitigation of $\mathrm{CO} 2$ emissions in Kosovo. It is used worldwide, and we cannot be an exception. The chemically tested Fly ash is added to concrete as cement substitute and the test results showed to positively approve its use. So, each one $\mathrm{kg}$ of cement substitution with fly ash is the one kilogram less $\mathrm{CO}_{2}$ in the atmosphere. Our physical and mechanical tests results showed that our concrete "absorbs" tons of $\mathrm{CO}_{2}$, being so friendly to environment, being friendly to people. This is a good track of Kosovo to comply with EU targets on reduction of GHG. The historians, as the named ages: "the stone age", "the bronze age", "the iron age", they must name our millennium: "the concrete age".
\end{abstract}

Keywords: Kosovo, Fly ash, GHG, Green Concrete, Sustainability.

\section{Introduction}

Concrete is the second most used material after the water [1] [2]. It is a mixture of aggregates, water, cement and admixtures. In an approximation for a mix design of a normal concrete mixture around 300 $\mathrm{kg}$ cement is needed for one cubic meter of concrete, i.e. around $12.5 \%$ by weight of concrete. All over the world there are produced more than 2Bt of cement annually. The increase of world's concrete consumption emerges the need to increase the cement production. Statistics showed that world production of concrete grew permanently. Considering 1994 as referent year with a world total cement production around 1.370 billion tons in 1994, in 2006 the cement production was 2.55 billion tons, in 20134.0 billion tons. The approximate calculation, in global scale, shows that production equals 555 kilograms per inhabitant annually [3]. If R. of Kosovo was not an exception, the cement production for each Kosovar would be the same summing the $1 \mathrm{Mt}$ of cement production or better said consumed annually.

Fly ash is a residue from lignite combustion in thermal power plants. The Kosovo abundance with lignite deposits around $14 \mathrm{Bt}$, ranking our country third in Europe for lignite resources [4], and having no other effective alternative of electrical energy production, this has oriented the sustainable energy production of Kosovo towards the use of fossil fuel, i.e. conversion of lignite energy to electrical one. That is the benefit of it. On the other side, this combustion, apart from gaseous emissions produces huge amount of particulate waste in the form of ash: bottom and fly ash. Expressed in percentage of the total ash, around $20 \%$ is bottom ash and $80 \%$ is fly ash which rises with flue gases. The fly ash is captured by ESP and it is discharged, together with bottom ash as hard waste. The quantity of ash depends on quantity of lignite combustion in the electricity production process. Over the years, the energy demands 
have increased the lignite consumption; the electivity production consumes around 7-8 Mt lignite annually. The combustion of this lignite, apart from bottom ash, produces $1 \mathrm{Mt}$ of fly ash annually. In 2003 the electricity generation was $3272 \mathrm{GWh}$, lignite consumption was $5.64 \mathrm{Mt}$, and fly ash production was $0.9024 \mathrm{Mt}$. In 2013 the electricity generation was $5864 \mathrm{GWh}$, lignite consumption 9.38 Mt and fly ash production $1.5008 \mathrm{Mt}$ [4], [5].

$\mathrm{CO}_{2}$ is a green house gas. It traps heat just like in a greenhouse and in this way enables the earth temperature to be around 15 Celsius degrees. Otherwise without green house effect the earth's temperature would be very low, minus 19 Celsius degrees. There are other GHG such as methane, water vapor, nitrous oxide $\left(\mathrm{N}_{2} \mathrm{O}\right)$. The effect of water vapor as $\mathrm{GHG}, 65 \%$ contribution, is greater than $\mathrm{CO}_{2}$ with $32 \%$ contribution, but the levels of $\mathrm{H}_{2} \mathrm{O}$ in atmosphere didn't change, or in our case, it can be said that it is not affected by human activities. If we refer to data about $\mathrm{CO}_{2}$, there is an increase of it by $25 \%, 280 \mathrm{ppm}$ two centuries before. The increase of $\mathrm{CO}_{2}$ was first declared in 1958, and the result showed $315 \mathrm{ppm}$. That was a matter of concern with $350 \mathrm{ppm}$ in 1990 . On the global scale, the amount of $\mathrm{CO}_{2}$ in the atmosphere reached 396.0 parts per million in 2013. At the current rate of increase, the global annual average $\mathrm{CO}_{2}$ concentration is set to cross the symbolic 400 ppm threshold in 2015 or 2016 [6].This is an indicator that the level of $\mathrm{CO}_{2}$ is increasing and the earth's temperature consequently. Knowing that approximately $5 \%$ of earth's $\mathrm{CO}_{2}$ is emitted from cement industry production, it is the aim of this study to mitigate the $\mathrm{CO}_{2}$ emissions from cement industry in the case of R. of Kosovo as part of global activities in cutting the carbon dioxide levels [7].

\section{Mitigation of Carbon Dioxide Emissions from Concrete Production by Substituting Cement with a Scientifically Reasonable Quantity of Fly Ash}

\subsection{Cement production and Carbon Dioxide Emission}

Cement is the basic material in concrete industry. The latest increase in construction industry demands greater cement consumption. The Cement production industry consequently contributes with $5 \%$ of global carbon dioxide emissions. On average, each year, three tons of concrete are consumed by every person on the planet, i.e. if we assume a $300 \mathrm{~kg}$ cement for 1 meter cube of concrete, it comes that around $500 \mathrm{~kg}$ cement is consumed by each earth's inhabitant [8].

The technological process of cement production requires high amount of energy, which can be in the form of thermal or electrical. A modern cement production factory consumes around $110-120 \mathrm{kWh}$ electrical energy per ton of cement [9]. In the case of Kosovo Power Plant, the specific emission of carbon dioxide is around $1.3 \mathrm{t} \mathrm{CO}_{2} / \mathrm{MWh}$. The calculation of indirect $\mathrm{CO}_{2}$ emission from electrical energy consumed in cement production is 0.0013 tons of $\mathrm{CO}_{2}$ per $\mathrm{KWh}$. This shows that per each ton of cement, only from the consumption of electrical energy the $\mathrm{CO}_{2}$ emission is around $0.15 \mathrm{tCO}_{2} / \mathrm{t}$ cement [5].

Other indirect carbon dioxide emission is from the thermal process required for heating the rotary kiln where the high temperature is required to perform the calcination process. The heat is provided by burning fossil fuel. It is known that the basic raw material for cement production is limestone $\mathrm{CaCO}_{3}$. The heat, typically between $850 \mathrm{deg} C$ and $1340 \mathrm{deg} C$ enables the endoterthmic decomposition reaction of $\mathrm{CaCO}_{3}$ into $\mathrm{CaO}$ and $\mathrm{CO}_{2}$. This endothermic reaction requires $3160 \mathrm{MJ}$ for producing. In the case of cement factory in R. of Kosovo the fuel for heating up the kiln is petcoke. For the reaction of calcinations there are required around $755 \mathrm{Mcal}$ which in $\mathrm{MJ}$ is 3161MJ [10]. Each MJ of heat from petcoke emits $97 \mathrm{~g} \mathrm{CO} 2$ [10]. Thus, the petcoke combustion emits $0.306 \mathrm{t}$ of $\mathrm{CO}_{2}$ per one ton of lime. The total of these two indirect $\mathrm{CO}_{2}$ emission is around $0.5 \mathrm{t} \mathrm{CO}_{2} / \mathrm{t}$ of lime, i.e. almost for one ton cement only from these two processes is half ton $\mathrm{CO} 2$ emitted in the air [11].

The increase of concrete demand in construction sector consequently leads to increase of cement production demand. The more cement produced the mores carbon dioxide emitted in the atmosphere and this GHG affects negatively the global warming. If not a total replacement of cement, a measure of mitigating its adverse effect could be possible. 


\subsection{Fly Ash- the Particulate Waste from Energy Production Process as Substituent of Cement in Concrete industry}

In terms of percentage more than $97 \%$ of electrical energy in Kosovo is generated from thermal power stations which use the lignite as fossil fuel. The impossible process of converting the total energy of lignite into electrical energy produces numerous other combustion byproducts. Many of them are emitted through the stack in the atmosphere. One other combustion byproduct is the ash. This ash rises with the flue gases and is captured by ESP. The total of this is around $80 \%$ of total ash and is called Fly ash. The rest, around $20 \%$ is bottom ash which is not subject of this paper. The quantity of ash that would be produced depends from the ash content in lignite that is around $14-17 \%$ by weight [3]. Quantitative analyses of fly ash production can be done based on the specific lignite consumption form the process of electricity generation. The data show that generation of $1 \mathrm{MWh}$ of electrical energy, in Kosovo TPP, consumes around 1.4t in Kosova B units, whilst in Kosova A 1.8t/MWh. To facilitate the calculation, a representative average is taken to be $1.6 \mathrm{t} / \mathrm{MWh}$ [12]. The growth in energy demand over the last years has led to the higher amount of lignite consumption. More lignite burnt means more particulate waste in the form of fly ash. An average of 7-8 Mt lignite consumption in a year produces around $1 \mathrm{Mt}$ fly ash presenting a huge environmental threat. In the table below is shown the energy generation, lignite consumption and fly ash production in Kosovo TPPs for the last decade.

Table 1. Energy production, lignite consumption and fly ash generation Quantity of ash generated from TPP Kosova A and B [12] [13]

\begin{tabular}{|c|l|l|l|l|l|l|l|l|l|l|l|}
\hline Year & 2003 & 2004 & 2005 & 2006 & 2007 & 2008 & 2009 & 2010 & 2011 & 2012 & 2013 \\
\hline $\begin{array}{c}\text { Energy } \\
\text { GWh }\end{array}$ & 3221 & 3481 & 3999 & 3970 & 4309 & $\mathbf{4 5 0 5}$ & 5260 & 5481 & 5696 & 5847 & 5864 \\
\hline $\begin{array}{c}\text { Lignite } \\
\text { Mt }\end{array}$ & 5.64 & 5.59 & 6.27 & 6.35 & 7.11 & 7.46 & 8.41 & 9.34 & 9.11 & 9.35 & 9.38 \\
\hline $\begin{array}{c}\text { BA+FA } \\
\text { Mt }\end{array}$ & 0.9024 & 0.8944 & 1.0032 & 1.016 & 1.1376 & 1.1936 & 1.3456 & 1.4944 & 1.4576 & 1.496 & 1.5008 \\
\hline
\end{tabular}

Table 2. Fly ash production over the last decade in Kosovo TPP

\begin{tabular}{|c|l|l|l|l|l|l|l|l|l|l|l|}
\hline Year & 2003 & 2004 & 2005 & 2006 & 2007 & 2008 & 2009 & 2010 & 2011 & 2012 & 2013 \\
\hline FA & 0.7219 & 0.7155 & 0.8025 & 0.812 & 0.9100 & 0.9548 & 1.0764 & 1.1955 & 1.1660 & 1.196 & 1.2006 \\
Mt & & & & & & & & & & & \\
\hline \hline
\end{tabular}

Fly ash production

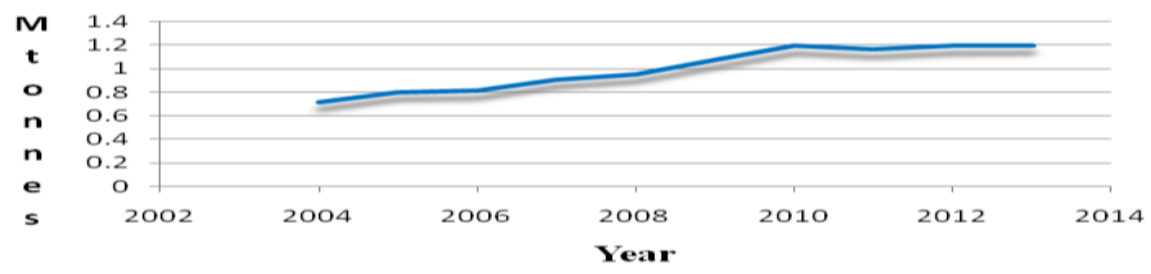

Fig. 1. Fly ash production over a ten year period

As it is presented the quantity of this particulate waste is growing due to the growth of energy demand. A possible way to reduce its impact in environment pollution, it is the alternative to utilize it. The first step is done through its chemical analyses. The fly ash of Kosova B TPP has been tested chemically and the chemical and mineralogical composition is shown in the table 3. 
Table 3. Chemical composition of Kosovo B Fly Ash [5]

\begin{tabular}{lll}
\hline Constituent & Chemical formulae & \%/ weight \\
\hline Silica & $\mathrm{SiO}_{2}$ & 29.7 \\
\hline Alumina & $\mathrm{Al}_{2} \mathrm{O}_{3}$ & 10.65 \\
Iron Oxide & $\mathrm{Fe}_{2} \mathrm{O}_{3}$ & 6.18 \\
\hline Lime & $\mathrm{CaO}$ & 32.92 \\
Magnesium oxide & $\mathrm{MgO}$ & 5.93 \\
Sulfur & $\mathrm{SO}_{3}$ & 9.98 \\
Sodium oxide & $\mathrm{Na}_{2} \mathrm{O}$ & 0.74 \\
Potassium oxide & $\mathrm{K}_{2} \mathrm{O}$ & 0.61 \\
\hline Loss on Ignition $($ LOI) & & 2.09 \\
\hline
\end{tabular}

Fly ash composition

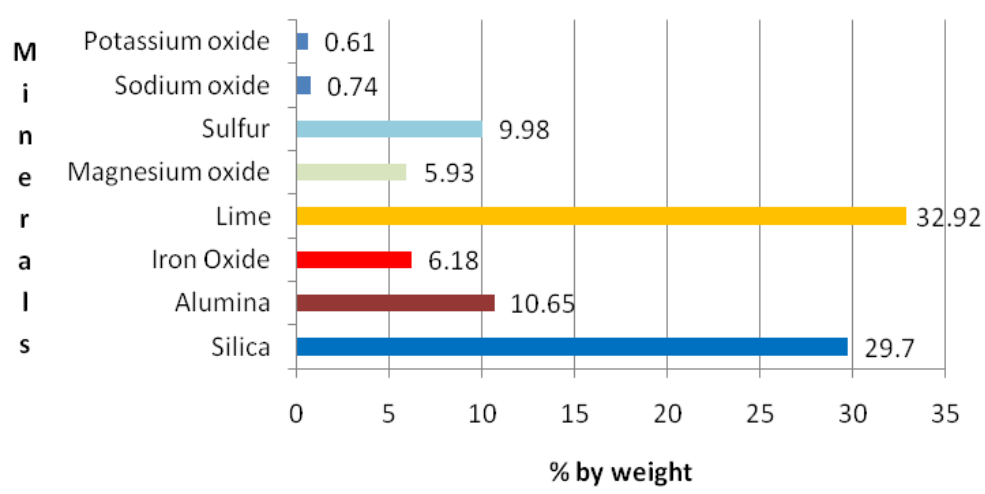

Fig. 2. Kosovo B Fly ash composition

The chemical composition shows that fly ash generally has the same content as cement, but in different percentage. That was the ground state that scientists, engineers based to treat it as possible cement replacement in concrete mix designs or admixture to cement itself.

This fine pulverized grey-in-brown colored material features cementituous and pozzolanic properties. According to EN 450-1 [14], that is European standard for Fly ash in concrete, fly ash is "Fine powder of manly spherical, glassy particles derived from burning of pulverized coal, with or without cocombustion materials, which has pozzolanic properties and consists essentially of $\mathrm{SiO}_{2}$ and $\mathrm{Al}_{2} \mathrm{O}_{3}$ ".

The classification of fly ash based on the American standard ASTM C618 12a [15]. This standard classifies the fly ash based on the content by mass of lime. If the lime content is greater than $20 \%$ by mass, the standard classifies it in Class C Fly ash. The fly ash from Kosovo B TPP showed to have $32.92 \% \mathrm{CaO}$ (testing method SIST EN 1971-1, clause 3.1) and is definitely classified as class $\mathrm{C}$ that in addition of pozzolanic properties has also cementitious properties.

The issue is that we have got million tons of this particulate waste from the energy sector that is not utilized, and on the other hand we have got million tons of $\mathrm{CO}_{2}$ emitted from cement manufacturing industry. Both, the fly ash and $\mathrm{CO}_{2}$ have an annual production rate that counts million ton. The impact of this paper is to use the fly ash in concrete as partial cement substituent. The outcome is done on the tests done with different percentage of fly ash replacing cement. Each kilogram of cement substituted by one kilogram of fly ash means one kilogram $\mathrm{CO}_{2}$ less in Kosovo's atmosphere. If we consider million tons of concrete production, that would be a great mitigation of this GHG from cement industry. 


\section{The Optimal Quantity of Fly Ash in Replacing Cement in building Eco-friendly Concrete}

\subsection{Concrete Mix Designs, Compressive Strength and consistence Tests}

There were designed several concrete mixes. The focus of all these tests has been the possibility of fly ash utilization in concrete as cement substituent. The method followed in test consists on the comparison of compressive strength and consistence of samples with different percentage of Fly ash to the one that it has been referred as referent one, which is designed and built with cement and admixture only. For each intended test there were prepared and cured carefully three samples and the aforementioned properties have been measured. The consistence was measured using the slump method, whilst the compressive strength with the destructive method by pressing them to the strain sustained maximally [1]. The cement is Portland cement, from local SHARRCEM factory, R. of Kosovo with trademark name Forca (CEM.I/52.5N) [16]. The aggregates have been used those from a local quarry, concrete production company NPTSH "VËLLEZERIT E BASHKUAR" shpk. The used aggregates were tested for: sieving method, shape index, determination of particle density and water absorption, sand equivalent test, resistance to fragmentation, resistance to wear, resistance to freezing and thawing, resistance to slat crystallization, chemical analyses and the petrographic examination. The tests were performed in accordance with requirements of standard EN 13043:2002/AC: 2004 [17], and EN 12620 [18].

\subsubsection{Referent mix design- Ref. MQDK-CTKK}

This concrete mix design contains in $1 \mathrm{~m}_{3}, 300 \mathrm{~kg}$ Portland cementm CEM I, $0 \mathrm{~kg}$ Fly ash, aggregate, water, TKK hiperplasticizer [19]. The consistency of fresh concrete measured using slump test was 180 $\mathrm{mm}$. There were prepared cubic samples, $15 \mathrm{~cm} \times 15 \mathrm{~cm} \times 15 \mathrm{~cm}$ with the same aforementioned design. The calculated fresh concrete density was $\rho=2448,2 \mathrm{~kg} / \mathrm{m} 3$.

\subsubsection{Mix Design with 15\% Fly Ash as Cement Replacement- MQDK-15 FA}

This concrete mix design contains in 1m3, $255 \mathrm{~kg}$ Cement CEM I, $45 \mathrm{~kg}$ Fly ash, aggregate, water, TKK hiperplasticizer. The consistency of fresh concrete measured using slump test was $130 \mathrm{~mm}$. There were prepared cubic samples, $15 \mathrm{~cm} \times 15 \mathrm{~cm} \times 15 \mathrm{~cm}$ with the same aforementioned design. The obtained fresh concrete density was $\rho=2440 \mathrm{~kg} / \mathrm{m} 3$.

\subsubsection{Mix Design with 20 \% Fly Ash as Cement Replacement- MQDK-20 FA}

This concrete mix design contains in 1m3, $240 \mathrm{~kg}$ Cement CEM I, $60 \mathrm{~kg}$ Fly ash, aggregate, water, TKK hiperplasticizer. The consistency of fresh concrete measured using slump test was $140 \mathrm{~mm}$. There were prepared cubic samples, $15 \mathrm{~cm} \times 15 \mathrm{~cm} \times 15 \mathrm{~cm}$ with the same aforementioned design. The obtained fresh concrete density $\rho=2430 \mathrm{~kg} / \mathrm{m} 3$.

\subsubsection{Mix Design with 25 \% Fly Ash as Cement Replacement- MQDK-25 FA}

This concrete mix design contains in $1 \mathrm{~m}^{3}, 225 \mathrm{~kg}$ Cement CEM I, $75 \mathrm{~kg}$ Fly ash, aggregate, water, TKK hiperplasticizer. The consistency of fresh concrete measured using slump test was $90 \mathrm{~mm}$. There were prepared cubic samples, $15 \mathrm{~cm} \times 15 \mathrm{~cm} \times 15 \mathrm{~cm}$ with the same aforementioned design. The calculated fresh concrete density $\rho=2430 \mathrm{~kg} / \mathrm{m} 3$.

\subsubsection{Mix Design with 30 \% Fly Ash as Cement Replacement- MQDK-30 FA}

This concrete mix design contains in $1 \mathrm{~m} 3,210 \mathrm{~kg}$ Cement CEM I, $90 \mathrm{~kg}$ Fly ash, aggregate, water, TKK hiperplasticizer. The consistence of fresh concrete measured using slump test was $80 \mathrm{~mm}$. There 
were prepared cubic samples, $15 \mathrm{~cm} \times 15 \mathrm{~cm} \times 15 \mathrm{~cm}$ with the same aforementioned design. The calculated fresh concrete density $\rho=2420 \mathrm{~kg} / \mathrm{m} 3$.

\subsubsection{Mix Design without Fly Ash and without Admixture- Ref. MQDK-C}

This concrete mix design contains in $1 \mathrm{~m} 3,300 \mathrm{~kg}$ Cement CEM I, 0 kg Fly ash, aggregate, water, $0 \mathrm{~kg}$ TKK hiperplasticizer. The consistency of fresh concrete measured using slump test was $10 \mathrm{~mm}$. There were prepared cubic samples, $15 \mathrm{~cm} \times 15 \mathrm{~cm} \times 15 \mathrm{~cm}$ with the same aforementioned design. The calculated fresh concrete density $\rho=2440 \mathrm{~kg} / \mathrm{m} 3$.

\subsubsection{Self Compacting Concrete Mix Design with Fly Ash- SCC ECO-FRIENDLY}

This concrete mix design contains in 1m3, $400 \mathrm{~kg}$ Cement CEM I, $100 \mathrm{~kg}$ Fly ash, aggregate, water, TKK hiperplasticizer. The slump flow spread measured was $580 \mathrm{~mm} \times 580 \mathrm{~mm}$. There were prepared cubic samples, $15 \mathrm{~cm} \times 15 \mathrm{~cm} \times 15 \mathrm{~cm}$ with the same aforementioned design. The calculated fresh concrete density $\rho=2400 \mathrm{~kg} / \mathrm{m} 3$.

\subsection{Review and Comparison of Test Results, Compressive Strength and Consistence of Concrete} Samples in Regard to Cement Replacement by Fly Ash in Concrete Mix Designs

\subsubsection{Compressive strength}

The experimental work consists of preparation of seven concrete mix designs. One mix design is prepared only with cement type CEM I, aggregate and admixture-superplasticizer TKK hiperplast 182. That is our referent sample. Four mix designs were done with a certain percentage of fly ash as cement replacement. The quantity of cement replaced with the percentage of fly ash is as in the following rate: 15\% (MQDK-15 FA), 20\% (MQDK-20 FA), 25\% (MQDK-25 FA) and 30\% (MQDK-30 FA) of Fly ash by weight of total cement designed for an ordinary concrete class. The water amount was held the same in all mixes. One other mix named SCC ECO-FRIENDLY is self-compacting concrete. The percentage of fly ash in this mix is $25 \%$ by weight of concrete. The first mix Ref. MQDK-C is an ordinary mix without fly ash and without admixture. After the curing, the samples have undergone the compressive tests in two different ages, 2 and 7 days. The next is planned after 28 days. The results of each test are presented in the Table 4.

Table 4. Compressive strength test results

\begin{tabular}{lccccc}
\hline Mix Design & $\begin{array}{c}\text { Age } \\
\text { 2 days } \\
\text { fc,cube } \\
\text { (MPa) }\end{array}$ & $\begin{array}{c}\text { Age } \\
\text { 7days } \\
\text { fc,cube } \\
(\mathrm{MPa})\end{array}$ & $\begin{array}{c}\text { Age } \\
\text { 28 days } \\
\text { fc,cube } \\
(\mathrm{MPa})\end{array}$ & $\begin{array}{c}\text { Increase } \\
\text { of CS } 2 / 7 \\
\text { days }(\%)\end{array}$ & $\begin{array}{c}\text { Increase } \\
\text { of CS } \\
7 / 28 \\
\text { days } \\
(\%)\end{array}$ \\
\hline Ref. MQDK-C & 14.95 & 24.35 & 34.38 & 61.40 & 70.83 \\
$\begin{array}{l}\text { Ref. MQDK- } \\
\text { CTKK }\end{array}$ & 26.95 & 37.6 & 47.43 & 71.68 & 79.27 \\
MQDK-15 FA & 25.05 & 36.15 & 49.03 & 69.29 & 73.73 \\
MQDK-20 FA & 21.43 & 31.7 & 46.02 & 67.60 & 68.88 \\
MQDK-25 FA & 19.21 & 32.45 & 47.86 & 59.20 & 67.80 \\
MQDK-30 FA & 13.94 & 23.96 & 39.37 & 58.18 & 60.86 \\
SCC & 44.02 & 55.95 & $* * *$ & 78.68 & $* * *$ \\
ECO- & & & & & \\
FRIENDLY & & & & & \\
\hline
\end{tabular}

The essence of the testing is to show the reasonability of fly ash utilization as cement replacement. If we refer to referent mix design Ref. MQDK-CTKK with admixture but without fly ash, it can be noticed 
a slight deficiency of compressive strength to those with fly ash: 15\%, 20\%, 25\% and 30\%. The greater the fly ash content, the lower the discrepancy in compressive strength. The $15 \%$ is slightly close to the referent one, the $30 \%$ has much lower compressive strength. The wonder that "spoils" this rule is mix SCC ECO-FRIENDLY, self compacting concrete. In two days test, the compressive strength of SCC is $17 \mathrm{MPa}$ higher than of that referent one- Ref. MQDK-CTKK, and for $29 \mathrm{MPa}$ stronger than the one without fly ash and admixture. That is why this is called Eco friendly concrete. In 7 days test, this difference in compressive strength increases, $19 \mathrm{MPa}$ difference to Ref. MQDK-CTKK, $31 \mathrm{MPa}$ to Ref. MQDK-C. One interesting fact that has been taken out form the test results is that even the concrete mix with highest fly ash content- 30\% with admixture, MQDK-30 FA, showed equal, or almost the same compressive strength as the mix with cement only without admixture. Four mixes that contain fly ash: MQDK-15 FA, MQDK-20 FA, MQDK-25 FA, MQDK-30 FA definitely showed higher compressive strength than Ref. MQDK-C, mix that has no fly ash and no admixture. At the age of 28 the test results showed that compressive strength of samples MQDK-30 FA is higher than of that referent, Ref. MQDK-C without TKK hiperplast and without fly ash and stronger than referent Ref. MQDK-CTKK with TKK hiperplast. The sample MQDK-25 FA showed to have equal compressive strength as Ref. MQDK-CTKK and Ref. MQDK-C. MQDK-15 FA showed to have higher compressive strength than Ref.MQDK-CTKK and Ref. MQDK-C. All these are in favor of fly ash utilization in concrete industry as cement replacement. And less cement from cement industry means less $\mathrm{CO}_{2}$ in the atmosphere. This double green concrete: it "absorbs" the particulate waste from the energy sector and it "absorbs" the $\mathrm{CO}_{2}$ from cement industry.

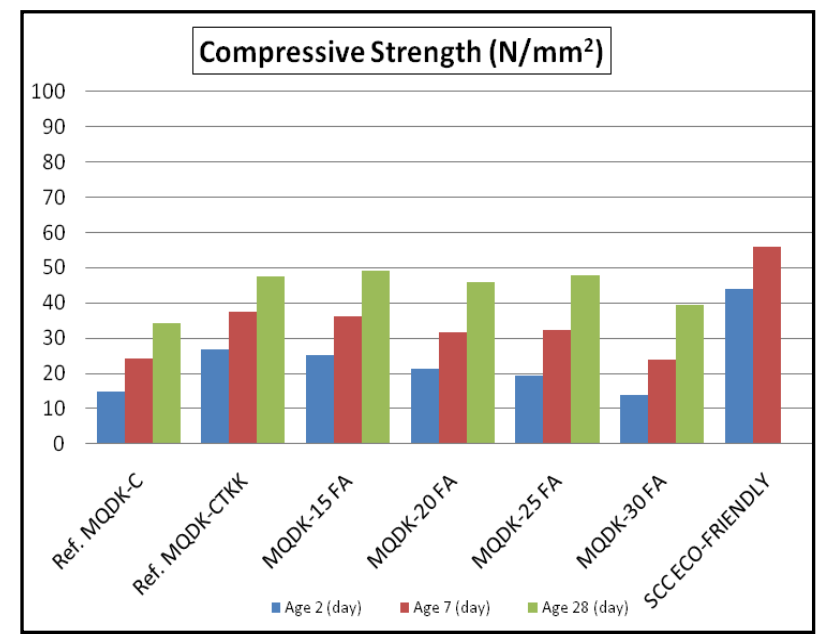

Fig. 3. Compressive strength of mix designs in two different ages

Table 5. Mix designs-content of Cement, Fly ash and TKK Hiperplast 182

\begin{tabular}{ccccc}
\hline Mix Design & $\begin{array}{c}\text { Cement } \\
\left(\mathrm{kg} / \mathrm{m}^{3}\right)\end{array}$ & $\begin{array}{c}\text { Fly ash } \\
(\mathrm{kg} / \mathrm{m} 3)\end{array}$ & $\begin{array}{c}\text { Hiperplast } \\
182 \\
\left(\mathrm{~kg} / \mathrm{m}^{3}\right)\end{array}$ & $\begin{array}{c}\text { fc,cube } \\
(\mathrm{MPa}), \text { After } \\
28 \text { days }\end{array}$ \\
\hline Ref. MQDK-C & 300 & 0 & 0 & 34.38 \\
Ref. MQDK-CTKK & 300 & 0 & 1.2 & 47.43 \\
MQDK-15 FA & 255 & 45 & 1.2 & 49.03 \\
MQDK-20 FA & 240 & 60 & 1.2 & 46.02 \\
MQDK-25 FA & 225 & 75 & 1.2 & 47.86 \\
MQDK-30 FA & 210 & 90 & 1.2 & 39.37 \\
SCC ECO- & 400 & 100 & 4.3 & (SCC) fck- \\
FRIENDLY & & & & $55.95^{*}$ \\
\hline
\end{tabular}


* (SCC) fck-55.95- this is the compressive strength after 7 days, there was no CS test of SCC at age 28 days.

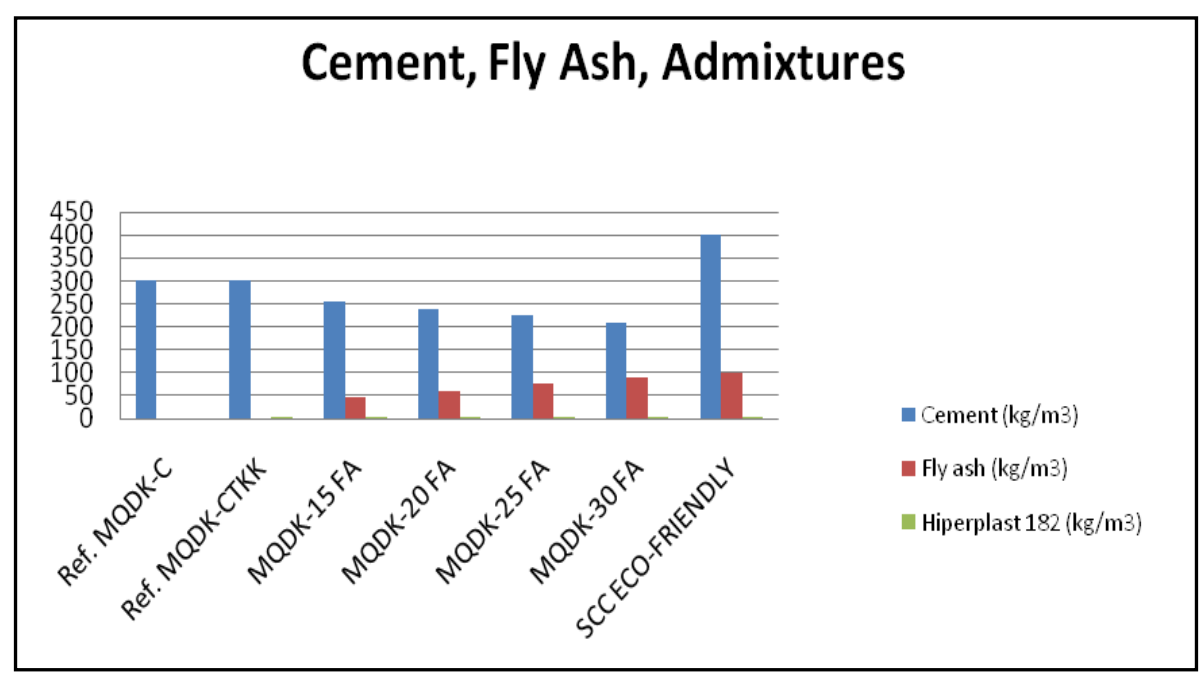

Fig. 4. Content of Cement, Fly ash and TKK Hiperplast 182

Table 6. Water Cement ratio, Water effective cement ratio, C+Fly ash, Water binder ratio

\begin{tabular}{lcccc}
\hline \multicolumn{1}{c}{ Mix Design } & W/C & Weff/C & $\begin{array}{c}\text { W/(C+k x fly } \\
\text { ash })\end{array}$ & W/Binder \\
\hline Ref. MQDK-C & 0.700 & 0.660 & 0.700 & 0.530 \\
$\begin{array}{l}\text { Ref. MQDK- } \\
\text { CTKK }\end{array}$ & 0.630 & 0.600 & 0.630 & 0.480 \\
MQDK-15 FA & 0.745 & 0.710 & 0.696 & 0.480 \\
MQDK-20 FA & 0.792 & 0.747 & 0.720 & 0.480 \\
MQDK-25 FA & 0.844 & 0.797 & 0.745 & 0.480 \\
MQDK-30 FA & 0.905 & 0.854 & 0.770 & 0.480 \\
$\begin{array}{l}\text { SCC } \\
\text { ECO- }\end{array}$ & 0.500 & 0.460 & 0.450 & $* * *$ \\
FRIENDLY & & & & \\
\hline
\end{tabular}

The water cement ratio for all concrete mixes has been shown in the Table 6 and Figure 5. From both it can be ascertained that concrete mixes with greater Fly Ash content, except SCC Eco-friendly mix have greater water-cement ratio. This is due to the fact that fly ash has been added in account of cement. Comparing to referent mix Ref. MQDK-CTKK, the SCC eco-friendly mix is in great advantage regarding the $\mathrm{w} / \mathrm{c}$ ratio. The other mixes that are slightly near this ratio are those with $15 \%$ and $20 \%$ Fly ash.

According to EN 206-1 fly ash is classified as Type II concrete additive, and then an explanation of $\mathbf{k}$-value shall be given for our case. This $\mathbf{k}$ value is a factor to be considered in the calculations of water in fresh concrete. The amount of fly ash that should be taken in into account for $\mathbf{k}$ value shall meet the requirements:

Fly ash /cement $\leq \mathbf{0 . 3 3}$ by weight. In case of excessive fly ash use, the extra shall not be taken into account in the calculation o water / (cement $\mathrm{x}$ fly ash) ratio and the minimum cement content. In our 
case, as we have used CEM I $52.5 \mathrm{~N}$, the $\mathrm{k}$ value to be taken in calculation is 0.4 . From all four mix designs with fly ash addition, $15 \%, 20 \%, 25 \%$ and $30 \%$, only the one with $30 \%$ fly ash exceeds the maximum k value, Fly ash /cement $\leq 0.33$ [14].

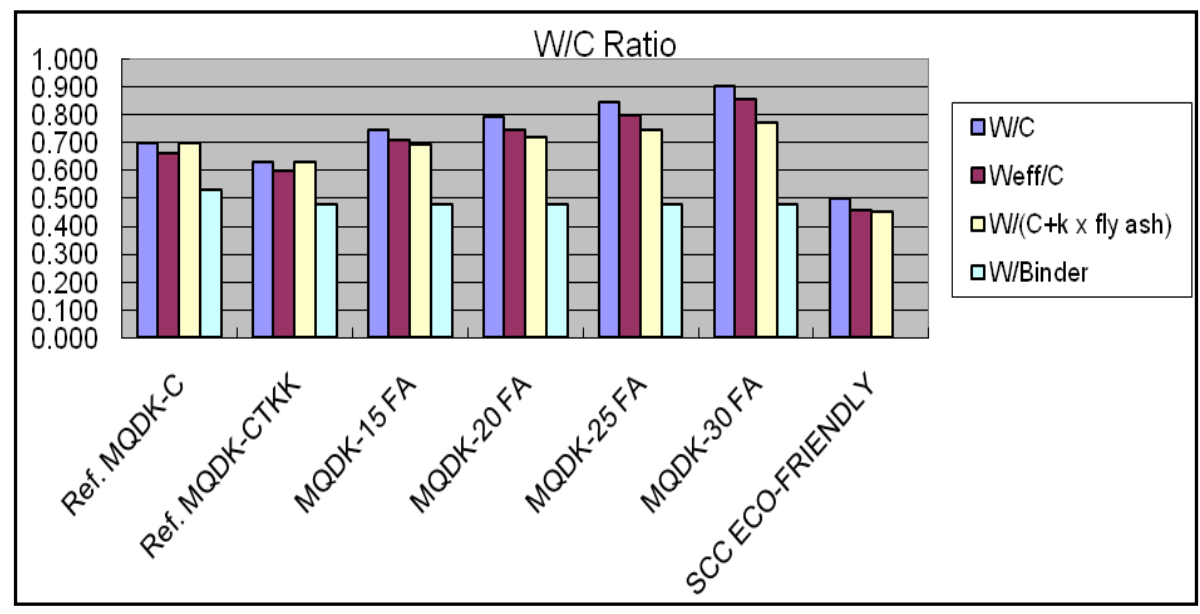

Fig.5. Water cement ratio

\subsubsection{Concrete Consistency-Slump Test in (mm)}

The consistence test of fresh concrete was done by slump method conform SK EN 12350-2. There were achieved different values of consistence. The term consistence is alternative term of workability. According to Glanville, et Al. (1947) [20], the workability is "the property of freshly mixed concrete or mortar which determines the ease and homogeneity with which it can be mixed, placed, consolidated and finished. Thus it represents a valuable property of fresh concrete. As we have designed different mix designs with different content of cement that was replaced by fly, the results showed in the table below were different.

Table 7. Consistence of fresh concrete of different mix designs

\begin{tabular}{lc}
\hline Mix Design & Slump test (mm) \\
\hline Ref. MQDK-C & 100 \\
Ref. MQDK-CTKK & 180 \\
MQDK-15 FA & 130 \\
MQDK-20 FA & 140 \\
MQDK-25 FA & 90 \\
MQDK-30 FA & 80 \\
SCC ECO-FRIENDLY & SF1* \\
\hline
\end{tabular}

* The slump flow test was done in accordance to EN 206-9:2010, 4 for SCC. The slump flow class according this standard is class SF1, i.e. 550-650 $\mathrm{mm}[21]$.

It can be figured out that two different mix designs have not same consistence. The consistence is mostly affected by the quantity of water and cement. In our case we substituted (or not) cement with a certain percentage of fly ash instead, whilst the water content was held the same as in the referent mix. 
As presented in the table and chart above, it can be easily stated that the replacement of cement with fly ash reduces the workability. That should be taken into consideration that addition of fly ash absorbs more mixing water.

\section{Conclusions}

The electrical energy produced in Kosovo TPP is not green at all: 97\% is from lignite combustion, less than $3 \%$ is green from water. The TPPs except gaseous pollutants that emit in the air, they produce around 1 million ton of hard waste in the form of fly ash that it has not been utilized. By the in-depth test analyses chemically, physically and mechanically, this waste can be partially used in concrete industry as cement substituent.

The compressive strength tests of several mix designs proved that this fly ash from Kosovo TPP can in a high percent be used in concrete. The most suitable percentage of fly ash by weight of cement that can replace cement showed to be around $15-25 \%$. All four mixes with fly ash proved to have greater compressive strength than the mix without fly ash and without admixture that usually this type of concrete is generally produced in Kosovo. Thus, with a little amount of admixture the concrete build with fly ash exceeds the compressive strength of that with cement only.

The cement industry is one of the greatest contributors to $\mathrm{CO}_{2}$ as GHG. The calculations show that each ton of cement "produces" also 1 ton of $\mathrm{CO}_{2}$. Half of the $\mathrm{CO}_{2}$ is from the chemical reaction of calcinations and half of it from the electrical energy for running the machinery and some portion from fuel combustion for reaching high temperature for producing clinker from lime stone.

Now, we have three facts: fly ash as waste, $\mathrm{CO}_{2}$ from cement and the one we are interested the replacement of cement in concrete by a reasonable content of fly ash. In terms of number this can be depicted as: if we replace $1 \mathrm{~kg}$ cement with $1 \mathrm{~kg}$ fly ash the effect is double positive. $1 \mathrm{~kg}$ of fly ash is removed from the nature and $1 \mathrm{~kg} \mathrm{CO}_{2}$ is "not" emitted in nature. If generally speaking, from 1 million tons of cement, if we substitute only $25 \%$, that is 250,000 tons less fly ash in our land and 250,000 tons less $\mathrm{CO}_{2}$ emission in the air.

\section{References}

1. SK EN 206-1 - Concrete. Part 1: Specification, performance, production and Conformity.

2. WBSD. Cmenent technology Roadmap 2009. World Business Council for Sustainable Developmnet. P.2 (2009); UNEP. Greeing Cement Production. Unites Nations Environment Programme, (2010).

3. http://www.lasyntheseonline.fr.

4. Energy Strategy and Policy of Kosovo, EU Pillar, PISG Energy Office.

5. M. Qafleshi, L. Aliko, Characterization, Classification and Standardization of Fly Ash of Kosovo Lignite-Fired Power Stations as Industrial Construction Product, IJMER, Vol. 3, Issue. 5, Sep - Oct. 2013, pp-3063-3070.

6. M. Qafleshi, D. R. Kryeziu, L. Aliko, particulate and gaseous pollutants as byproducts from the combustion process in lignite fired power plants. Case: Kosova A and Kosova B Thermal Power Plants, ICRAE2014, ISSN: 2308-0825, 2014, Shkoder, Albania.

7. http://www.wmo.int/pages/mediacentre/press_releases/pr_1002_en.html.

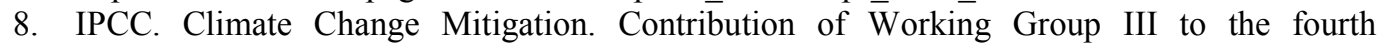
Assessment Report. Intergovernmental Panel on Climate Change. Section 7.4.5.1: MineralsCement, 2007.

9. http://blogs.ei.columbia.edu/2012/05/09/emissions-from-the-cement-industry, Earth Institute, Columbia University.

10. G. Mejeoumov, Improved cement quality and grinding efficiency by means of closed mill circuit modeling, 2007.

11. http://www.afpm.org/policy-position-petroleum-coke. 
12. Kosovo Energy Corporation, KEK statistical data, Strategic development office, 2013.

13. http://www.kostt.com. KOSTT, Transmission, system and market operator, J.S.C.

14. Fly ash for concrete, Part 1: Definition, specifications and conformity criteria. EN 4501:2005+A1:2007.

15. ASTM, American Society for Testing and Materials, Standard Specification for Coal Fly Ash and Raw or Calcined Natural Pozzolan for Use in Concrete.

16. http://sharrcem.com/wp-content/uploads/2013/12/Broshura-Sharrcem-52.5-FORCA2012.pdf

17. EN 13043:2002/AC: 2004, Aggregates for bituminous mixtures and surface treatments for roads, airfields and other trafficked areas

18. EN 12620 Aggregates for concrete

19. EN 934-2, Admixtures for concrete, mortar and grout - Part 2: Concrete admixtures Definitions and requirements

20. P. L. Domone, Fresh Concrete, advanced Concrete technology, Elsevier Ltd, 2003, Great Britain

21. EN 206-9:2010 Concrete. Additional rules for self-compacting concrete (SCC)

22. EN 1008, Mixing water for concrete - Specifications for sampling, testing and assessing the suitability of water, including wash water from recycling installations in the concrete industry, as mixing water for concrete. 